\title{
Hva er egentlig narkotika?
}

\author{
Narkotika er det vi forskriver på A-resepter. Eller?
}

Ordet narkotika (flertallsform av narkotikum) er avledet fra det greske ordet narce, som betyr bedøvelse. Et narkotikum er altså et bedøvende middel - eller, mer presist, et middel som kan indusere stupor, koma og analgesi (1). Hvis man tar utgangspunkt i denne definisjonen, hvilket man gjør både i engelskspråklig litteratur («narcotics») og medisinskfaglig sammenheng, er begrepet synonymt med morfinliknende bedøvende midler (1). Med andre ord: Narkotika er det samme som opioider.

Denne betydningen synes over tid å ha blitt erstattet av en mer juridisk tolking, der ordet narkotika brukes som en samlebetegnelse for alle ulovlige eller reseptbelagte rusgivende substanser, uavhengig av deres farmakologiske egenskaper (1). I Norge er for tiden 264 substanser - samt derivater av disse - klassifisert som narkotika i den såkalte «narkotikalisten» (2). Siden det er store ulikheter i disse substansenes farmakologiske egenskaper, og siden listen stadig utvides, har det blitt vanskelig å besvare spørsmålet «hva er et narkotikum?» uten å havne i en sirkelargumentasjon av type «noe som omfattes av narkotikalisten».

\section{Vanedannende legemidler}

Det er viktig å være oppmerksom på at den juridiske definisjonen av narkotika er mer omfattende enn den «folkelige» oppfatningen av begrepet, som vanligvis begrenser seg til illegale rusmidler som cannabis, kokain, amfetamin og heroin (fig 1). Den juridiske definisjonen - det vil si narkotikalisten - omfatter også mange stoffer som brukes terapeutisk, altså såkalte vanedannende legemidler. Mange av disse midlene, blant annet seks benzodiazepiner og 15 opioider, er markedsført i Norge (fig 1). I Norge plasseres disse i reseptgruppe A (legemidler med høy misbruksfare) eller B (legemidler med misbruksfare) etter vurdering hos Statens legemiddelverk (3). Det er imidlertid ikke slik at legemidler i reseptgruppe A og B utgjør en entitet tydelig atskilt fra illegale narkotika. Potensielt vanedannende substanser som ikke har markedsføringstillatelse i Norge (som for eksempel cannabis), kan forskrives legalt på godkjenningsfritak, og blant legemidler som er markedsført i Norge, finner vi blant andre et «klassisk narkotikum» som morfin og et «folkelig/ juridisk narkotikum» som amfetamin. Det

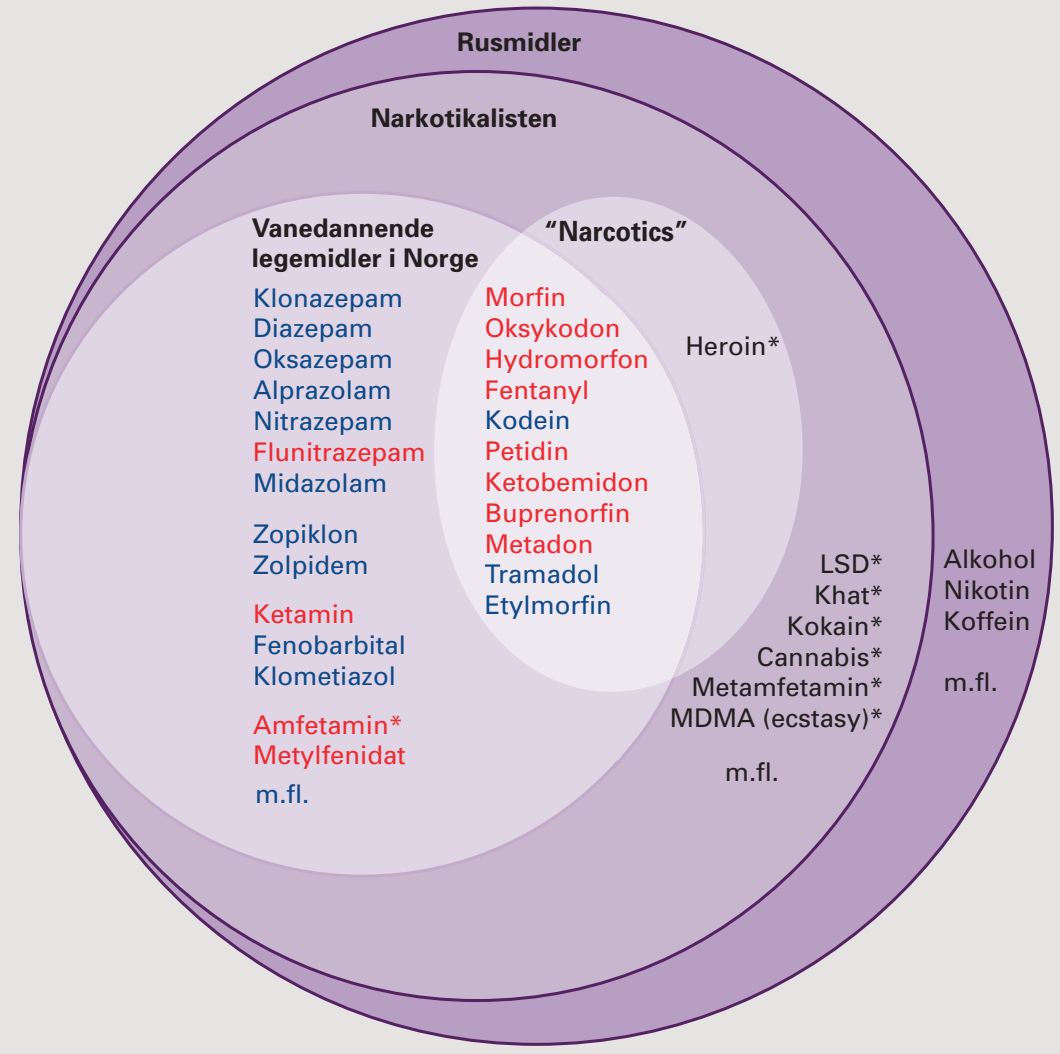

Figur 1 Ulike definisjoner av begrepet «narkotika», vist i et venndiagram. Ytre sirkel omslutter midler som kan gi brukeren en eller annen form for rus. Sirkelen med overskrift «narkotikalisten» omslutter midler som klassifiseres som «narkotika» i henhold til norsk lov. Innenfor denne omslutter sirkelen til venstre vanedannende legemidler som er markedsført i Norge. Her vil leger ofte omtale A-preparatene (rød skrift), men ikke B-preparatene (blå skrift), som «narkotika». Den lyseste sirkelen omslutter den historisk/engelskspråklige definisjonen av «narkotika», det vil si analgetika i opioidklassen. Midler merket med stjerne er de som «folk flest» assosierer med begrepet «narkotika»

er med andre ord umulig å dra en tydelig grense mellom legemidler og narkotika.

\section{Begrepsforvirring}

Innholdet $\mathrm{i}$ begrepet narkotika avhenger altså av hvem man spør; en angloamerikaner vil svare «opioider», mannen i gata vil svare «rusmidler som cannabis, amfetamin, kokain og heroin», mens en norsk jurist trolig vil svare «samtlige rusmidler og legemidler på narkotikalisten». En norsk lege vil mest sannsynlig svare «legemidler i reseptgruppe A». I Norge er det nemlig blitt vanlig - ikke minst blant leger - å omtale A-preparater som «narkotika», mens B-preparatene gjerne omtales som «vanedannende legemidler» (4). Den daglige bruken av betegnelsene illustrerer begrepsforvirringen, og kan - uansett hvilken leir man hører hjemme i - være feilaktig: Alle A- og B- preparatene er vanedannende legemidler, og i henhold til norsk lov er de alle også narkotika (fig 1) $(2,3)$.

\section{Konklusjon}

Narkotikabegrepet har så mange og upresise betydninger at det med fordel kan forlates. Ordet kan dessuten være belastende, både for «de narkomane» og for pasienter som må bruke «narkotika» for å mestre hverdagen (5). WHO foreslår at man bytter ut ordet narkotika med mer presise betegnelser; f.eks. opioider, hvis det er de som skal omtales (1). Som samlebetegnelse kan narkotikabegrepet med fordel sparkes helt 
ut av helsevesenet, og i andre sammenhenger erstattes med en mer nøytral og presis betegnelse som for eksempel «rusmiddel». I den forbindelse er det kanskje også verdt å merke seg at «rusmiddel» står i Tidsskriftets liste over nøkkelord, mens «narkotika» ikke gjør det.

\section{Andreas Austgulen Westin}

andreas.westin@legemidler.no

Avdeling for klinisk farmakologi

St. Olavs hospital

7006 Trondheim

\section{Elin Johanne Hansteen Strøm}

Lade Behandlingssenter Blå Kors

\section{Tarjei Rygnestad}

Avdeling for smerte og sammensatte lidelser St. Olavs hospital

og

Institutt for laboratoriemedisin,

barne- og kvinnesykdommer

Norges teknisk-naturvitenskapelige universitet

\section{Lars Slørdal}

Institutt for laboratoriemedisin,

barne- og kvinnesykdommer

Norges teknisk-naturvitenskapelige universitet og

Avdeling for klinisk farmakolog

St. Olavs hospital

Andreas Austgulen Westin (f. 1977) er lege i spesialisering ved Avdeling for klinisk farmakologi.

Elin Johanne Hansteen Strøm (f. 1970) er lege ved Lade Behandlingssenter Blå Kors.

Tarjei Rygnestad (f. 1954) er spesialist i anestesiologi og klinisk farmakologi og professor.

Lars Slørdal (f. 1955) er spesialist i klinisk farmakologi og professor.

\section{Litteratur}

1. World Health Organization. Lexicon of alcoho and drug terms. www who int/substance abuse/ terminology/who lexicon/en (14.6.2011).

2. FOR-1978-06-30-8 Forskrift om narkotika m.v (narkotikalisten). www.lovdata.no/for/sf/ho/ to-19780630-0008-0.html (22.6.2011)

3. FOR-2009-12-18-1839 Forskrift om legemidler (legemiddelforskriften), kapittel 7. http://www. lovdata.no/for/sf/ho/xo-20091218-1839.html (22.6.2011).

4. Rønning M, Berg C, Furu K et al. Reseptregisteret 2005-2009. Tema: Vanedannende legemidler. Oslo: Nasjonalt folkehelseinstitutt, 2010 : $11-20$.

5. Rygnestad T, Slørdal L. Domsslutninger, derivatregler og «designer drugs»: Manglende faktaforståelse i strafferettspleien vedrørende misbruksstoffer? Lov og rett 2010; 49: 223-9.

Mottatt 16.5. 2011, første revisjon innsendt 14.6 2011, godkjent 15.6. 2011. Medisinsk redaktør Raida Ødegaard. 